\title{
Fostering Maritime Innovations Through Human Capital: Exploring the Status Quo of the Adriatic Universities
}

\section{Poticanje pomorskih inovacija kroz ljudski kapital: istraživanje statusa quo sveučilišta u Jadranskome moru}

\author{
Senka Šekularac - Ivošević \\ University of Montenegro \\ Faculty of Maritime Studies Kotor \\ E-mail: senkas@ucg.ac.me
}

\section{Summary}

The purpose of the paper is to emphasize the need for enhancing participation of the Adriatic maritime universities and researchers in modern innovation processes in maritime industry. The paper primarily analyses human capital in regard to two constituent components - academic (academic rank and the length of research experience) and collaborative (expertise in innovation projects, the frequency of participation, the constraints related to partnerships and funds). The research is based on quantitative and qualitative analysis. The dependence between the components associated with human capital is quantitatively determined by means of the Pearson's chi-square test and the R programme. The qualitative analysis relies on coding of the attitudes of the maritime researchers about collaborative innovations in maritime industry. The coding was performed by means of the Atlas.ti 8.4.24. programme. Results confirm the significance of human capital for maritime research, identify constraints on the realization of innovations and specific innovations the maritime researchers are working on. Additionally, the paper detected the lack of strategic transformation of the universities that would strengthen collaborative innovations in maritime industry. The paper proposes formation of collaborative network/platform for an efficient use of human capital in scientific research and maritime and economic integrations in the Adriatic region.

\section{Sažetak}

Cilj ovoga rada je istaknuti potrebu za većim sudjelovanjem pomorskih sveučilišta i znanstvenika u Jadranu u modernim inovacijskim procesima u pomorskoj industriji. Rad prvenstveno analizira ljudski kapital u odnosu na dvije sastavne komponente akademsku (akademski stupanj i duljina znanstvenoga iskustva) i suradničku (stručno znanje u inovacijskim projektima, učestalost sudjelovanja, ograničenja u odnosu na partnerstvo i fondove). Istraživanje se temelji na kvantitativnoj i kvalitativnoj analizi. Zavisnost između komponenti povezanih s ljudskim kapitalom ustanovljena je kvantitativnom analizom uz pomoć Pearsonovoga hi kvadrat testa i R programa. Kvalitativna analiza oslanja se na kodiranje stavova znanstvenika u pomorstvu prema suradničkim inovacijama u pomorskoj industriji. Kodiranje je provedeno uz pomoć Atlas.ti 8.4.24. programa. Dobiveni rezultati potvrđuju značaj ljudskog kapitala u pomorskim istraživanjima, identificiraju ograničenja u realizaciji inovacija i specifičnih inovacija na kojima rade znanstvenici u pomorstvu. Pored toga, u radu je utvrđen nedostatak strateške transformacije sveučilišta kojom bi se ojačale suradničke inovacije u pomorskoj industriji. $U$ radu se predlaže stvaranje suradničke mreže / platforme za učinkovitu uporabu ljudskog kapitala u znanstvenim istraživanjima i pomorskim $i$ ekonomskim integracijama u području Jadrana.

\author{
DOI 10.17818/NM/2021/3.6 \\ UDK 378:656.61 \\ 005.331 \\ Preliminary communication / Prethodno priopćenje \\ Paper accepted / Rukopis primljen: 19. 2. 2021.
}

\section{KLJUČNE RIJEČI \\ pomorska industrija \\ ljudski kapital \\ suradnička inovacija \\ sveučilište \\ područje Jadrana}

\section{INTRODUCTION / Uvod}

Innovation in maritime industry is frequently considered a determinant of success [1]. Most contemporary definitions of 'innovation', which resulted from a long process, rely on two defining characteristics - a degree of the newness of a change and a degree of usefulness or success in application [14]. Innovation as a concept was analysed in different contexts, but the overall stance is that innovations replace old products/ services and technologies, positively affect turnover as well as the competition that sustains and strengthens economic growth [23]. Modern maritime logistic chains involve a lot of stakeholders, technologies, data exchanges and complex relationships between different parties. A better integration of the elements in these chains and a higher competitiveness of chains require technological innovations of processes as well as non-technological innovations such as organizational, managerial and institutional innovations [according to 8].

The literature presents a traditional attitude that maritime industry is less open to innovations in comparison with other industries [1]. However, the past decades indicate significant changes in that regard. A space for collaboration and a fruitful 
ground for innovations came from the adjustment of the world and maritime industry to the dual challenges of increased sustainability and digital development [11]. The twenty-first century innovations in maritime business are implemented through varied projects and focus primarily on the following business aspects: maritime energy efficiency, safety, the evaluation and reduction of negative effects of shipping on climate, the environment and public healthcare, e-maritime, sustainable working conditions within shipping industry, integrated transport systems and business models, alternative energy for ship propulsion and energy supply, innovative shipping concepts and naval architecture, financial incentives supporting the transition to sustainability within maritime industry, etc. $[26,19]$.

Considering the fact that maritime innovations become increasingly widespread, the realization and commercialization of innovative ideas should be further enhanced. In the past, companies had to rely on internal resources and efforts. However the previous two decades witnessed a change in business relations between companies because they have changed their collaborative paradigms, from linear innovation model to open innovation model introduced by Chesbourb (2003) [3]. The linear model is based on individual research within the R\&D centres, while the open model introduced by implies the formation of new, interlinked communities. Triple helix model [25] and the models of maritime clusters, which are further enhanced and still prominent in maritime industry, represent the precursors of the open model [22]. In that sense, open innovation, collaborative and/or collective innovation represent the key concepts [12]. Collaborative innovation is the term that best matches the purpose and aim of the paper.

Collaborative innovation starts when an organization becomes open for collaboration with other organizations such as suppliers, partners, competitors, universities, research and technology centres and institutes, start-ups, customers and government institutions and other organizations that can contribute with valuable novelties. Collaborative innovation is based on integration and commercialization of complementary resources and capabilities among the participants, which increases the value and benefits of an innovative activity [8]. It was proven that properly managed R\&D projects that rely on open innovation partnerships (both, science-based and marketbased) have a better financial performance [9].

Modern universities consider collaborative innovations to be spin-off activities which expand the functions of universities from traditional, educational and research activities, to entrepreneurial activities. The conceptualization of the paper faces a dilemma whether the business paradigm of the Adriatic universities is linear or open. The presence of human capital whose knowledge, skills and experience coincide with the needs of companies and other stakeholders involved in innovation processes will undoubtedly lead to the enhancement of regional competitiveness [15]. Accessibility and connections among skilled and highly qualified people in maritime areas are important for long-term and short-term competitiveness and sustainability of maritime sector. Universities and research centres play an essential role in the provision of human capital. In that sense, universities make multiple contributions:

In terms of education, universities provide human capital for innovation;
In terms of research, universities ensure knowledge (co-) production for private and public value creation;

In terms of knowledge exchange for innovation systems, universities enable technology transfer and multi-actor cocreation; and

In terms of strategic transformation, universities embed innovations [24].

This research was motivated by a notable lack of official studies on maritime innovations in the countries of the south Adriatic (e.g. in Montenegro and Albania). The countries surrounding the region are considered to be moderate innovators (e.g. Croatia and Slovenia) whose innovative performance is still below the EU average innovation performance [10, p. 14]. The Adriatic region should be accordingly investigated in the context of its potential for maritime innovations through intensive collaboration and knowledge exchange. In that way the region would gain a better position in maritime market and exploit the advantages of the correlation among innovations, competitiveness and economic growth and development.

It was assumed that the research results would sustain the results of previous studies in terms of the identification of the following issues [6]:

An insufficient degree of cooperation between networks formed by agglomeration or geographical polarization of maritime industry, public institutions and regulatory bodies, universities and other stakeholders that interact with them; A need for interaction between "stakeholders that produce knowledge" and their "potential customers"; and

- An increased need for the understanding of the importance of knowledge management and innovation, as well as the activities based on knowledge-intensive services in the context of increasingly globalized competition.

The concept of academic intellectual capital is highly complex and comprises of three dimensions - researchers' human capital and the nature of social and organizational capitals of the team in which a researcher is integrated [7]. The paper focuses on the first dimension i.e. researchers' human capital. The research initially concerns four research questions (RQ) that examine the attitudes of the Adriatic maritime researchers:

RQ1: What is the current status quo of the human capital for maritime research?

$R Q 2:$ What are recent innovations in maritime industry?

RQ3: What are the constraints to collaborative innovations?

RQ4: What is the current role of universities in collaborative innovations?

It was assumed that academic and collaborative components determine the potential of human capital for collaborative maritime innovations. Therefore, the paper investigates the relationship between these components (Fig. 1). The academic component includes academic rank and the length of research experience. The collaborative components are: expertise in maritime innovation projects, the frequency of participation, the constraints on the establishment of partnerships, and the constraints on the provision of financial resources.

In order to measure human capital, various studies investigated experience, competences, personality, education levels, social skills, intelligence, skills and qualifications, as well as "less tangible" characteristics [20]. Modern studies 
examined research knowledge, research competences, dynamic capabilities, working capacity and critical thinking [7]. In that sense, the paper examines available and tangible academic components of human capital. There were two initial hypotheses:

H1: There is a relationship between academic rank and the frequency of the participation in maritime innovation projects.

H2: There is a relationship between the length of research experience and the expertise in maritime innovation projects.

The main challenges for the implementation of innovative projects are related to funds and partnerships [16, 4, 13]. In a broad sense, the main constraints on innovation are: the lack of qualified workers/partners and financial provision, the lack of information, plagiarism, the percentage of cooperation per sector, legal protection index per sector, etc. [4]. The term "expertise" indicates the knowledge that the researchers gained from innovation project implementation [according to 2]. In that regard, the research examined the following three hypotheses:

H3: There is a relationship between the length of research experience and the frequency of participation in maritime innovation projects.

H4: There is a relationship between the length of research experience and the constraints on the establishment of partnerships in maritime innovation projects.

H5: There is a relationship between the length of research experience and the constraints on the provision of financial resources for maritime innovation projects.

In terms of the constraints on the establishment of partnerships, innovations are related to the sensitivity of information outflow. Therefore, the initiators of innovations are less likely to establish new partnerships in open market and prefer collaboration with the existing partners [25]. Long-term, trustworthy relationships are highly important as well as the trust in the R\&D collaboration, and the connections among the stakeholders involved in innovation processes $[4,13]$.

Financial resources are inhibiting factors that impose (1) barriers to capability and (2) barriers to willingness. Some of the barriers to capability are related to experimenting, prototypetesting, purchase of innovative components, the costly exploration of new ideas, and the testing of prototype parts. The barriers to willingness refer to the motivational challenges of teams [16].

The paper aims to detect the potential of human capital for the maritime research and the constraints to the realization of maritime innovation projects. Furthermore the paper examines the role of universities in collaborative maritime innovations and specific innovations the maritime researchers from the Adriatic universities are working on.

\section{METHODOLOGY / Metodologija}

The role of researchers in the development and commercialization of innovations in maritime industry were rarely investigated in the past. For that reason, this study adopted an exploratory approach. In accordance with the exploratory approach, the study relies on a survey investigating the attitudes of the academic researchers. The research sample included 45 researchers from six maritime faculties [21]. The researchers are from the universities in Albania, Croatia, Montenegro and Slovenia.

Figure 2 shows that the paper relies on the set of five logically related steps - the formulation of ideas and research concept, the definition of the research objectives and research questions, primary research and data collection, research results analysis and synthesis, and specific outcomes for science and practice. The paper relies on a mixed method - statistical data analysis (the R programme) and qualitative analysis (the Atlas. ti 8.4.24. programme). The first research question was subjected to quantitative analysis, while the remaining questions were subjected to qualitative analysis.

Initial research questionnaire described the purpose of the paper, specific questions and instructions and was electronically delivered to the researchers. The questionnaire contains the total of 13 questions - general information about the researchers (4 questions), quantitative scale questions (6 questions) and openended questions (3 questions).

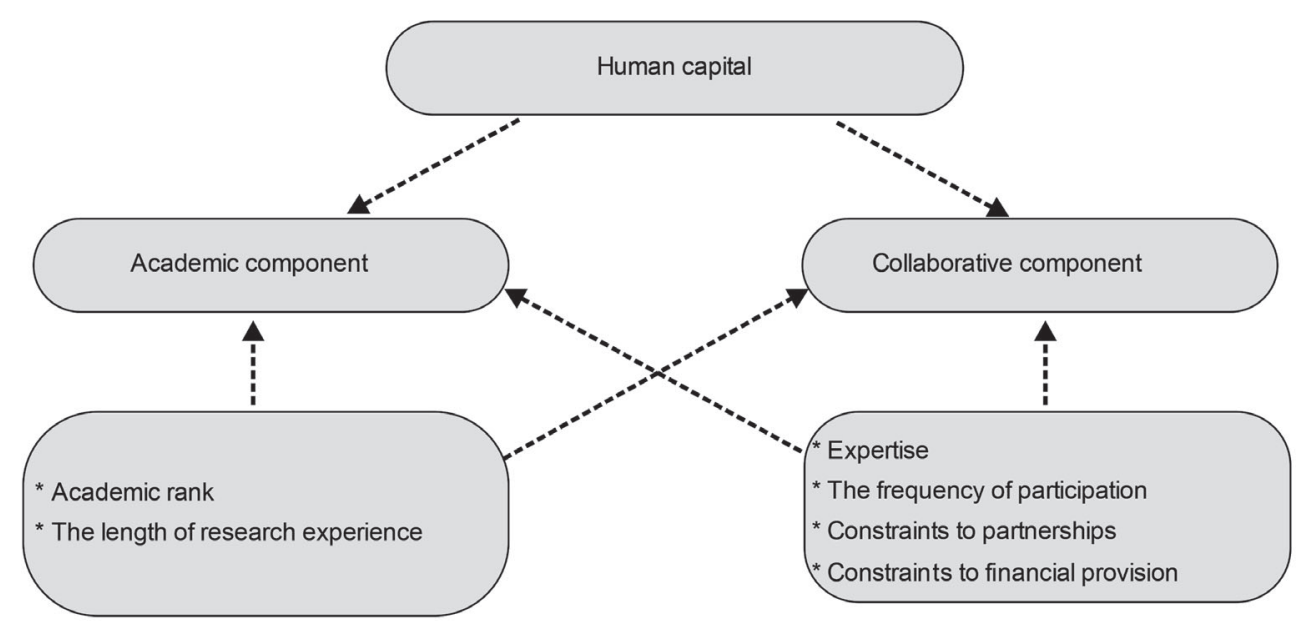

Figure 1 The conceptual model Slika 1. Konceptualni model

Source: Created by author 


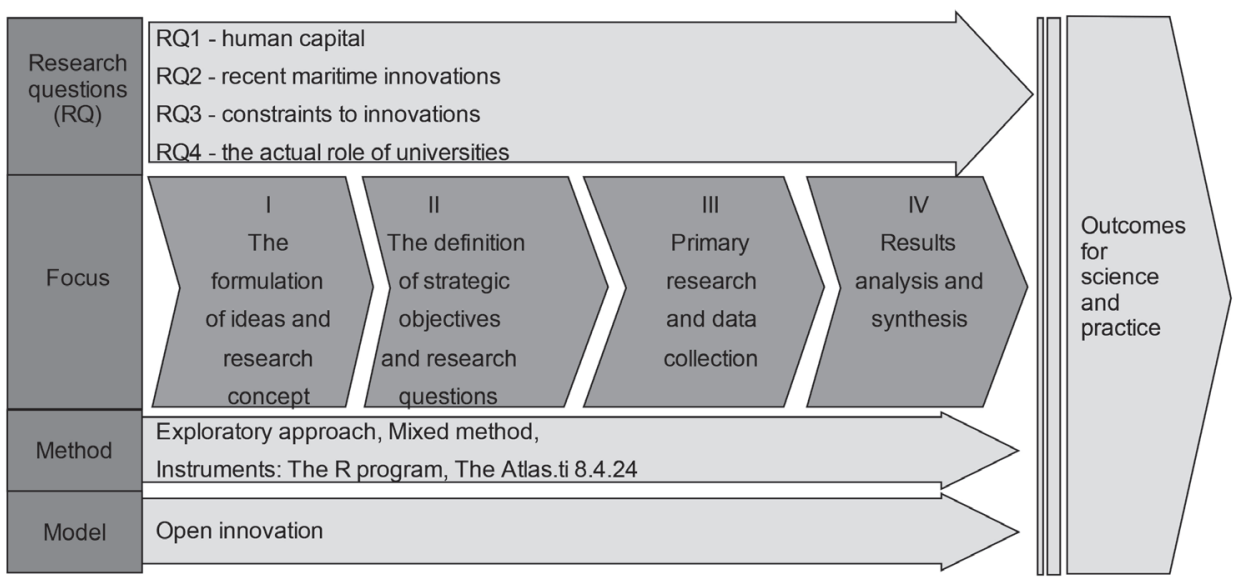

Figure 2 The methodological framework of the paper Slika 2. Metodološki okvir rada

Source: Created by author

The basic methodological selection of the questions is aimed to increase the broad understanding of the behavior of academic researchers, constraints and innovations in maritime industry. The attitudes of the researchers were measured by means of nominal and ordinal scales. On the other hand, three open-ended questions provide an in-depth insight into the topic of the research: 1) What are some of the recent maritime innovations that you investigate or were involved in? 2) What is your opinion about the role of the university in the context of collaborative innovations in the maritime industry? 2) What challenges are related to the collaborative innovation projects?

All hypotheses were tested by means of the R programming language which is a software for statistical calculations. The $\mathrm{R}$ programme is a programming language used for statistical calculations, data analysis and graphical representation of data. The $\mathrm{R}$ programme is frequently used in academia for the experiments with research data. The paper utilizes this programme because of its efficient mechanism for the creation of data structures. Additionally, graphics are an essential part of data analysis and the R programme easily produces graphs for data exploration. Research data have missing values which are an integral part of the $R$ programme as the programme contains several functions that control missing values.

Pearson's chi-squared test was applied to each variable (academic and collaborative component of the human capital investigated). Chi-square statistics is a measure of discrepancy between data and models. A chi-square equation can be analysed in the following way [17]:

$$
\chi 2=\sum_{i=1}^{n} \frac{\left(O_{i}-E_{i}\right)^{2}}{E_{i}},
$$

$$
\begin{aligned}
& X^{2}=\text { chi-square statistics } \\
& \mathrm{Oi}=\text { observed frequency } \\
& \mathrm{Ei}=\text { expected frequency } \\
& \mathrm{i}=\text { cell number (cell } 1, \text { cell } 2, \text { etc.) }
\end{aligned}
$$

Chi-square test indicates $\mathrm{p}$-value. $\mathrm{P}$-value suggests if test results are significant or not. In order to perform a chi-square test and obtain p-value, two pieces of information are required:

- The degree of freedom (the number of categories minus 1); and

- The alpha level (a) (The level can be chosen by a researcher). Usual value of alpha level is 0.05 (5\%).

The standardized residual is a measure of the strength of the difference between the observed and expected values. Residual shows the significance of cells for chi-square value. After the comparison of cells, standardized residual easily recognizes the cells with the highest contribution and the cells whose contribution is low.

The Atlas.ti 8.4.24. programme enables the formation of codes that are used for qualitative analyses. Coding is an interpretive process meant to capture the essence or the central theme of a portion of data collected through the survey questions. The following sections will provide graphical representations of the results obtained and corresponding comments.

\section{RESULTS AND DISCUSSION / Rezultati i rasprava 3.1. The Profile of the Maritime Researchers / Profil znanstvenika u pomorstvu}

The participants in the research were the academic maritime experts from the Adriatic region and their characteristics are presented in Table 1.

Initially, the researchers had to select their research fields among 20 maritime fields listed in the questionnaire [18]. Some of the researchers selected more than one field, so the total number of the responses obtained was 94 . The most researched area pertains to technical sciences, while less investigated were the areas of social sciences and humanities. After the selection of the research fields, the researchers were identified on the basis of their academic rank. The academic professionals include assistant professors, associate professors, teaching assistants, full-time professors and lecturers.

Besides the research field and academic rank, the researchers were also identified based on the length of their research experience. This indicates that the Adriatic region has qualified researchers who have solid research experience that can be used in fostering collaborative innovations in maritime industry.

\subsection{Quantitative Analysis in the R programme / Kvantitativna analiza u $R$ programu}

In accordance with the first hypothesis $(\mathrm{H} 1)$, the analysis in the $\mathrm{R}$ programme aimed to detect the existence of the connection between academic ranks and the frequency of participation in maritime innovation projects. The results obtained are: $x^{2}$ $(20)=26.192$ and $p=0.1384$. The value of $p(p>0.05)$ rejected the first hypothesis and proved that academic ranks and the frequency of participation in innovation projects are not related. 
Table 1 The characteristics of the maritime researchers

Tablica 1. Karakteristike znanstvenika u pomorstvu

\begin{tabular}{|c|c|c|}
\hline Characteristics & Frequency & (\%) \\
\hline \multicolumn{3}{|l|}{ The area of research } \\
\hline Marine engineering & 15 & 15.96 \\
\hline Marine ecology & 8 & 8.51 \\
\hline Ecology and sea & 8 & 8.51 \\
\hline Safety and security & 8 & 8.51 \\
\hline Education in transport & 8 & 8.51 \\
\hline Navigation & 7 & 7.45 \\
\hline Marine automation and electronics & 6 & 6.38 \\
\hline Transportation and modes & 5 & 5.32 \\
\hline Human resources in transport & 5 & 5.32 \\
\hline Marine information systems & 4 & 4.26 \\
\hline Management of marine systems & 4 & 4.26 \\
\hline Intelligent transport systems & 3 & 3.19 \\
\hline Maritime law & 2 & 2.13 \\
\hline Maritime health & 2 & 2.13 \\
\hline Up-to-date technologies & 2 & 2.13 \\
\hline Marine defence & 2 & 2.13 \\
\hline Language for specific purposes & 2 & 2.13 \\
\hline Hydrography & 1 & 1.06 \\
\hline Marine finance & 1 & 1.06 \\
\hline Applied mathematics & 1 & 1.06 \\
\hline Others & - & - \\
\hline Total & 94 & $100 \%$ \\
\hline \multicolumn{3}{|l|}{ Academic rank } \\
\hline Full-time professor & 7 & 15.56 \\
\hline Associate professor & 12 & 26.67 \\
\hline Assistant professor & 14 & 31.11 \\
\hline Lecturer & 4 & 8.89 \\
\hline Teaching assistants & 8 & 17.78 \\
\hline Others & - & - \\
\hline Total & 45 & 100.00 \\
\hline \multicolumn{3}{|l|}{ Years of research experience } \\
\hline No experience & 5 & 11.36 \\
\hline$<5$ & 7 & 15.91 \\
\hline $6-10$ & 10 & 22.73 \\
\hline $11-15$ & 10 & 22.73 \\
\hline $16-20$ & 3 & 6.82 \\
\hline$>20$ & 9 & 20.45 \\
\hline Total & 44 & 100.00 \\
\hline
\end{tabular}

Source: Created by author

Fig. 3 shows that full-time professors occasionally participate in maritime innovation projects (purple colour), unlike assistant and associate professors who frequently participate in these projects (green colour).

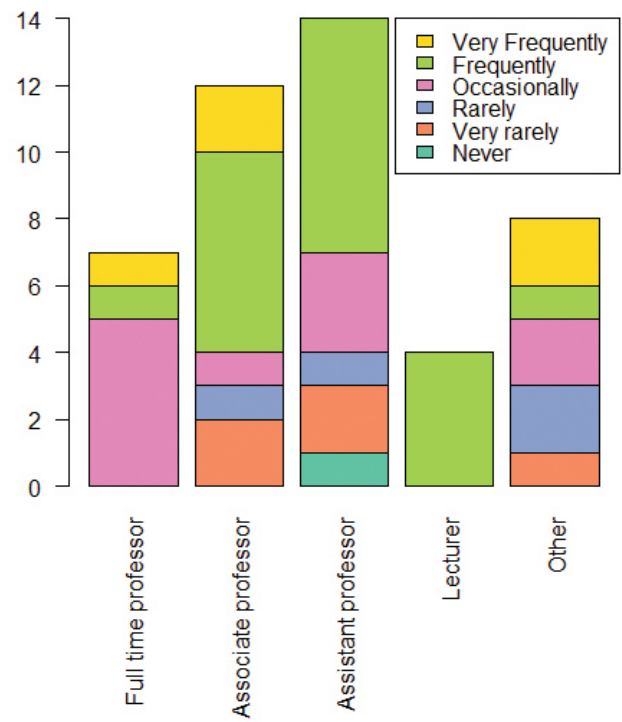

Figure 3 The frequency of participation in innovation projects in relation to academic ranks

Slika 3. Učestalost sudjelovanja u inovacijskim projektima u odnosu na akademski stupanj
This is explained by the fact that the researchers at the beginning of academic careers work on their PhD theses and tend to reach the standards of the elections to academic titles, which requires more extensive research as well as teachingresearch balance. Previous studies confirmed people who are in the twilight of their careers are assigned more teaching and administration tasks than research activities [5, p. 164].

The second hypothesis $(\mathrm{H} 2)$ investigated the subjective attitudes of the maritime researchers about their expertise in maritime innovation projects. It was assumed that the academic professionals whose research experience is short do not have great expertise in innovation projects and vice versa. The hypothesis was tested by means of Pearson's chi-square test whose results were: $\chi 2(20)=31.889$ and $p=0.04148$. The value of $p(p<0.05)$ confirmed the second hypothesis and proved that there is a relationship between the length of research experience and expertise in innovation projects. Blue circles indicate a positive correlation between the values of the rows and columns while red circles indicate negative ones (Fig. 4). 


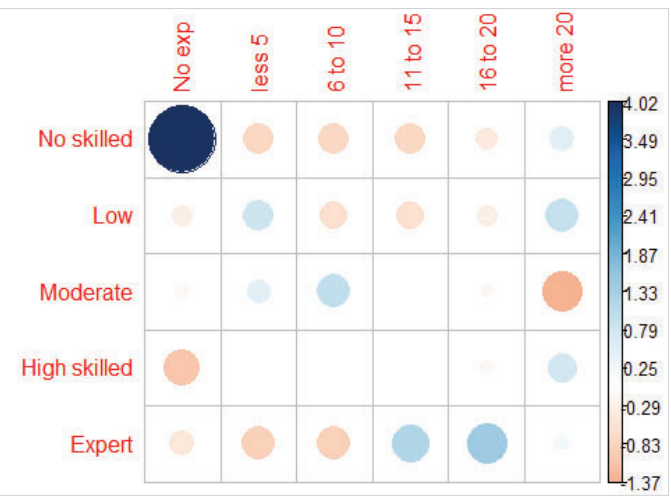

(a)

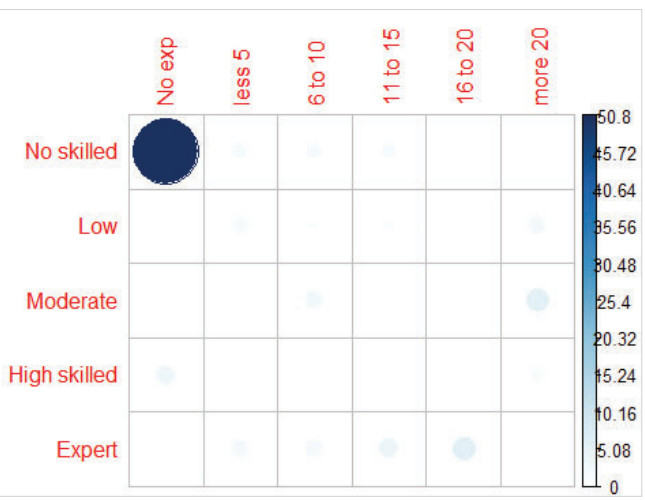

(b)

Figure 4 The relationship between the length of research experience and expertise in maritime innovation projects Source: Created by author Slika 4. Odnos između duljine znanstvenoga iskustva i stručnosti u projektima pomorskih inovacija

The size of a circle is proportionate to the value of cell contribution to the total value of chi-square statistics. Figure 4(a) exhibits a strong correlation between "unskilled" and "inexperienced", which was expected. Figure 4(b) shows the most contributing cells to the Chi-square are:

- Inexperienced/unskilled (50.801\%),

- 16-20 years/experts (6.324\%),

- More than 20 years/moderately skilled (5.889\%).

These cells contribute to the total score of chi-square about 63.014\% and thus explain most of the differences between the expected and the obtained values.

The comparison of these results with the data from Table 1 indicates that the lowest number of maritime researchers from the Adriatic region consider their current research experience to be at an expert level. There are more researchers whose experience is longer than 20 years and who consider themselves to be moderately skilled. In addition to these two groups, innovation projects could also involve the researchers whose experience is between 11 and 15 years due to a positive relationship between the experience and expert knowledge (Fig. 4).

The testing of the third hypothesis $(\mathrm{H} 3)$ indicated the frequency of participation of the Adriatic maritime researchers in maritime innovation projects. The frequency depends on the length of research experience. The hypotheses were tested through Person' chi-square test which showed that $x 2(25)=$ 46.768 and $p=0.006497$. The value of $p(p<0.05)$ confirmed

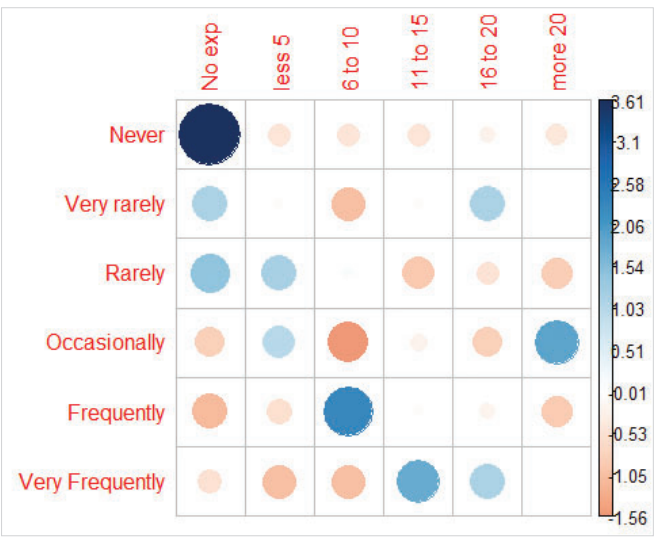

(a) the third hypothesis and proved that the length of research experience is related to the frequency of participation in maritime innovation projects (see Fig. 5).

A strong correlation is observed between "inexperienced" and "never involved" and between "11 to 15 years of research experience" and "very frequent" (Fig. 5(a)). Fig. 5(b) shows the cells with the highest contribution to chi-square:

- Inexperienced/never (27.939\%),

- 6 to 10 years of work experience/frequently (11.560\%), and

- More 20 years of work experience/occasionally (7.620\%).

These cells contribute to the total chi-square score about $47.119 \%$ and thus explain most of the differences between the expected and the obtained values. There is a notable relationship between frequent participation in innovation projects and the research experience varying between 6 and 10 years (Fig. 5). The comparison with Table 1 shows that in relation to the entire sample, researchers with between 6 and 10 years of experience actively participate in projects. The frequent participation of these researchers was also substantiated by the research results. These findings are substantiated by the same arguments as the first hypothesis.

According to the fourth hypothesis $(\mathrm{H} 4)$, it was assumed that the maritime researchers with longer research experience are more likely to establish partnerships for maritime innovation projects. The hypothesis was tested through Pearson's chi-square test whose results were: $x 2(15)=24.284$ and $p=0.06042$. The

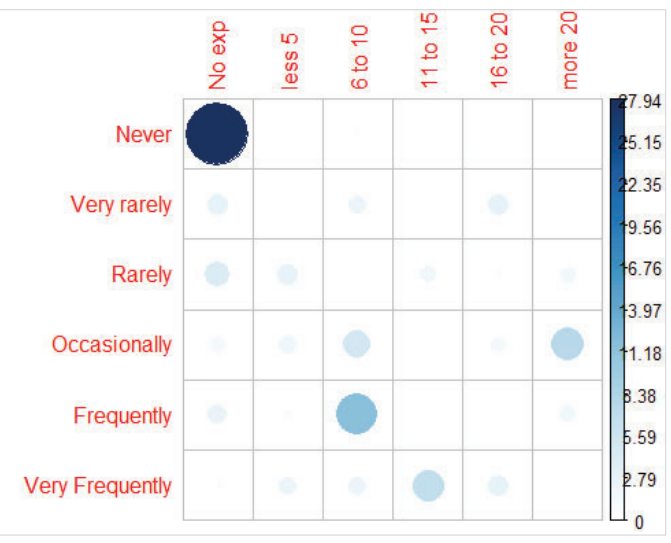

(b)

Figure 5 The connection between the length of research experience and the frequency of participation in maritime innovation projects

Slika 5. Povezanost između duljine istraživačkog iskustva i učestalosti sudjelovanja u projektima pomorskih inovacija Source: Created by author 
value of $p(p>0.05)$ rejected the fourth hypothesis and proved that the length of research experience is not related to the constraints on partnerships for maritime innovation projects (Graph 1).

The establishment of partnerships refers to several factors: a) the knowledge and the references of maritime researchers, b) the deadlines for project submission and, c) the type of innovation calls in relation to priority areas of maritime innovation. In that sense, the knowledge and references of maritime researchers have major significance for the establishment of partnerships. However, the deadlines are sometimes very tight, which is an additional obstacle to the partnerships. Likewise, considering the fact that maritime technology and science develop rapidly, it is difficult to find maritime experts for innovative fields and the development of human capital up to the level of expert is too long.

Based on Graph 1, it can be concluded that the attitudes about the difficulties in the establishment of partnerships are ambivalent - in other words, neutral attitude is prevalent.

The analysis of the fifth hypothesis (H5) disputed the relationship between the length of research experience and the constraints on the provision of financial resources for innovation projects. The hypothesis was tested by means of Pearson's chisquare test which resulted in: $x 2(15)=21.167$ and $p=0.1329$. The value of $p(p>0.05)$ rejected the fifth hypothesis and denied the existence of the relationship between the variables mentioned.

Most of the maritime researchers consider the provision of financial resources an obstacle (Graph 1), which could be the consequence of strong competition in project ranking by funding institutions. However, the literature suggests that the relationship between financial constraints and innovation project performance is moderated by a bounded creativity approach, which is "a team process that leverages the team's domain-relevant skills, an engaging project objective, strong team cohesion, and team potency" [16]. The findings related to the constraints on collaborative maritime innovations indicate that the maritime researchers surveyed should initiate close, long-term and trustworthy collaborations.

\subsection{The Attitudes of the Maritime Researchers about Collaborative Maritime Innovations / Stavovi znanstvenika u pomorstvu o suradničkim inovacijama u pomorstvu}

The responses to open-ended questions were gathered in 37 documents that were inputted into the Atlas.ti 8.4.24. programme. The programme generated 21 codes that were classified in 3 groups: 1) Recent innovations (8), 2) Constraints (6), and 3) The role of universities (7).

\subsubsection{Recent Innovations in Maritime Industry / Najnovije} inovacije u pomorskoj industriji

Table 2 exhibits the attitudes of the maritime researchers about the recent maritime innovation projects they participated in.

The majority of the researchers was involved in the innovations in maritime electronics and automation systems. They reported that these fields include autonomous ships, electronics, digitalization, the Internet of Things, e-navigation, STTC (Sea Traffic Control Centres), automatic mooring, autonomous tugboats, block-chain technology, virtual payments (bitcoin), automation of ports (terminals, vehicles), cyber security, digital innovations, and 3D printing.

Table 2 Recent Innovations in Maritime Industry Tablica 2. Najnovije inovacije u pomorskoj industriji

\begin{tabular}{|l|l|}
\hline Code & No. of Responses \\
\hline 1. Maritime electronics and automation systems & 18 \\
\hline 2. Maritime education and training & 7 \\
\hline 3. Marine ecology and protection & 5 \\
\hline 4. Maritime security and safety & 5 \\
\hline 5. Alternative sources of energy & 4 \\
\hline 6. Blue economy & 4 \\
\hline 7. Advanced materials in maritime industry & 2 \\
\hline 8. Marine Resources & 1 \\
\hline Total & 46 \\
\hline
\end{tabular}

Source: Created by author

The innovations in maritime education and training include the investigation and application of new learning methods, advanced simulators, advanced methodology in maritime education, distance learning, VR and AR-based applications that combine digital technologies and learning. The goal of these innovations is the improvement of educational process and visual acquisition of knowledge.

The innovations in marine ecology and protection refer to innovative approaches to the reduction in fuel consumption and the minimization of exhaust emission from ships (mostly CO2). Additionally, innovations in this field are related to "bubble technology" which represents hybrid energy systems with fuel cells (i.e. "Pa-X-ell2" project for the AIDAnova cruise ship), etc. This technology generally receives a lot of attention in the domain of blue growth.

The innovations in maritime security and safety deal with the research on maritime risk, STCW convention and, safety and cyber security. The alternative sources of energy refer to ship

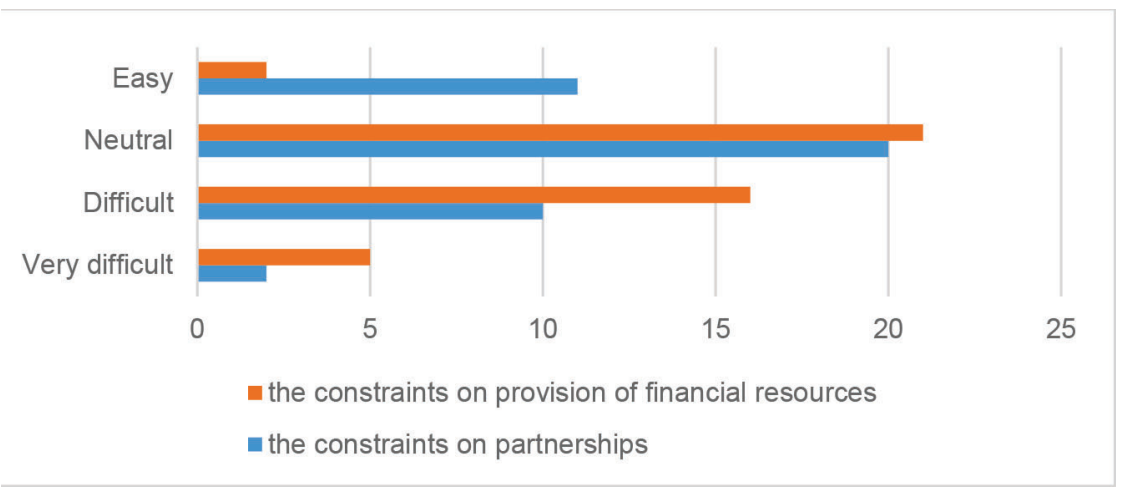

Graph 1 Constraints on the realization of innovation projects Grafikon 1. Ograničenja u realizaciji inovacijskih projekata 
propulsion, the exploitation of wind power and the application of renewable energy to boats and small ships.

The blue economy focuses on the research on prominent topics concerning tourism and marinas, blue economy, and sustainability. The innovations in relation to advanced materials in maritime industry include the examination of the characteristics of materials and the measurement of their functionality over extended shipping periods. The innovations regarding marine resources refer to the exploration of fisheries, aquaculture, desalination, offshore oil and gas, etc.

The qualitative analysis confirmed that the Adriatic maritime researchers work on specific projects and simultaneously observe contemporary maritime fields that are being innovated.

\subsubsection{The Constraints on Collaborative Maritime Innovations / Ograničenja u suradničkim inovacijama u pomorstvu}

Table 3 exhibits the attitudes of the maritime researchers about the constraints on collaborative innovations in maritime industry, based on the participation in different projects. One of the main constraints on the realization of innovations is the provision of financial resources as well as the risk that the project will not be successfully completed. These challenges inhibit the realization of maritime innovative ideas.

Table 3 The constraints on collaborative maritime innovations Tablica 3. Ograničenja u suradničkim inovacijama u pomorstvu

Code No. of Responses

\begin{tabular}{|l|c|}
\hline 1. Lack of funds & 12 \\
\hline 2. Lack of partnerships & 10 \\
\hline 3. Project management challenges & 10 \\
\hline 4. Non-stimulating environment & 9 \\
\hline 5. Lack of maritime experienced staff & 7 \\
\hline 6. Lack of infrastructure and equipment & 1 \\
\hline Total & 49 \\
\hline
\end{tabular}

Other difficulties noticed among the maritime researchers were the composition of consortiums, which belongs to the code labelled as "the lack of partnership". There were also claims that industry is closed for cooperation and considers R\&D unimportant since "new ideas are waste of money and time". The researchers from several maritime countries indicated that state administration does not support science, collaboration and the exchange of knowledge with universities.

The code labelled as "project management challenges" refers to the difficulties in finding suitable calls for maritime innovation projects, complicated administration, time management, tight deadlines, delayed deliveries of reports, complex communication with different partners, and difficulties in finding project managers. The researchers particularly highlighted the problem of time management because the preparation of project proposals combined with regular work represents "the overload of maritime academic staff with excessive scientific tasks and teaching, instead of the work on implementation of innovations, ability, and eagerness of team members to conduct innovation projects." Other challenges include the lack of strategy and long-term vision, the lack of executive support as well as the demotivation of team members, maritime stakeholders, and target groups.
Non-stimulating environment represents a group of challenges including: bureaucracy, the lack of public awareness, insufficient information, the lack of legal regulations of certain research fields, institutions with insufficient understanding of corporate culture, uncertainty about the future of the R\&D projects, political and economic instability of the area, resistance to the new methods of learning and working, the ignorance of experts, the lack of understanding of the importance of wellbeing and networking, the fear of new working practices and resistance to them. The maritime researchers also believe that the maritime innovation projects should be more promoted.

The main challenges in the domain of maritime human potential are the lack of competitive, skilled, and experienced people. The policy of the recruitment of maritime academic staff at universities was also seen as questionable, while the lack of academic researchers specialized in maritime fields was considered the main reason for an insufficient human capital for innovations. The lack of maritime laboratories and equipment was selected among other challenges in the list.

\subsubsection{The Role of Maritime Universities / Uloga pomorskih sveučilišta}

Table 4 presents the attitudes about the role of universities in collaborative maritime innovations. The role of maritime universities, the R\&D centres and human capital is considered highly important. In that sense, most of the maritime researchers had positive ideas, but were lacking plans for the realization of the ideas.

Table 4 The role of universities in collaborative maritime innovations

Tablica 4. Uloga sveučilišta u suradničkim inovacijama u pomorstvu

\begin{tabular}{|c|c|}
\hline Code & No. of Responses \\
\hline 1. Not determined & 12 \\
\hline 2. Connective leadership & 7 \\
\hline $\begin{array}{l}\text { 3. Education: providing human capital for } \\
\text { innovations }\end{array}$ & 5 \\
\hline 4. Industry as a leader in innovations & 5 \\
\hline $\begin{array}{l}\text { 5. Knowledge exchange for innovation systems: } \\
\text { technology transfers and multi-actor co-creation }\end{array}$ & 4 \\
\hline $\begin{array}{l}\text { 6. Research: knowledge (co-)production for private } \\
\text { and public value creation }\end{array}$ & 3 \\
\hline 7. Universities embed innovations & 0 \\
\hline Total & 36 \\
\hline
\end{tabular}

Source: Created by author

Connective leadership implies the attainment of a leading position in maritime innovation processes. According to the maritime researchers, a leading position could be achieved through networking, interaction and innovative systems that are initiated by maritime universities rather than maritime industry. The role of universities was described in the following ways: "Universities should be more oriented toward the needs of maritime industry; universities should connect different maritime stakeholders, define the common area of interest and be the primum movens of maritime innovations and strong bond between maritime partners".

The educational role of universities is considered "the most important contribution to regional innovation, as universities 
educate students and prepare them for diverse roles in future academic and professional development and leadership in maritime industry." Another view indicates that "for universities and their regional partners, the central concerns are related to a sufficient quantity and relevant quality of human capital" and raises a question - "Are there enough graduates and do they have the right maritime skills and competences?" A general stance of the maritime researchers is that universities should generate ideas for new jobs in maritime economy and suggest new policies and sustainable regulations that would enable the implementation of new ideas.

Some maritime researchers claim that maritime industry dominates over universities in innovation processes: "Other maritime stakeholders should say what kind of innovation they need and finance its realization, while universities should provide knowledge and know-how for the realization of maritime innovations".

The role of universities is defined as "knowledge exchange for innovation systems such as technology transfers and multiactor co-creation". In that sense, the maritime researchers see the role of universities as "the establishment of collaboration with several maritime stakeholders that exchange knowledge and include civil society; the development of support services for start-ups and vacancies for (mainly PhD) maritime students and researchers".

Finally, universities have a role in the stimulation of regional innovations and (co-) production of relevant knowledge. In that sense, universities represent "a motor of regional (or national) innovations" and have to define an intersection and balance between international research and regional relevance. Relevant knowledge has to reflect the boundaries of international research in thematic maritime fields in order to ensure academic excellence and help companies or public stakeholders face global challenges. Universities provide maritime stakeholders with the access to a "global pipeline" of knowledge required for maritime innovation processes.

The attitudes about the complete transformation of the universities toward embedded maritime innovations are not isolated. These views motivate broader and more extensive research on the strategies and models for the reinforcement of new roles of the maritime universities examined.

\section{CONCLUSIONS / Zaključci}

Available literature lacks extensive research on the potential of human capital for maritime research and innovation in the Adriatic region. Moreover, no previous study has investigated the strategies for the strengthening of the entrepreneurial role of the Adriatic maritime universities and researchers in collaborative innovations in maritime industry. To the best of the author's knowledge, this is the first study that aims to fill this gap from the perspective of reference discipline, which confirms the originality of the paper.

The paper answered four research questions. The Adriatic universities abound in the potential of young maritime researchers who participate in maritime innovation projects (RQ1). Considering the variety of the maritime fields that the researchers investigate, maritime sector is seen as a multidisciplinary research filed. The greatest human capital was observed in the field of maritime technical disciplines, which is confirmed by specific maritime innovations that the researchers developed so far (RQ2). The initially suggested constraints on the realization of maritime innovations were the lack of partnerships and the lack of funds. However, further analysis revealed 4 new constraints - project management challenges, non-stimulating environment, the lack of experienced maritime staff and the lack of infrastructure and equipment (RQ3). The attitudes of the maritime researchers indicated that the Adriatic universities have not still reached the level of strategic transformation that would enable the embedding of innovations in maritime industry, which means that the universities examined have a rather linear than collaborative paradigm (RQ4).

In terms of theoretical contribution, the paper presents the comprehensiveness of the components that comprise human capital at the Adriatic maritime universities. Additionally, the paper proposed conceptual method which graphically presents the dependence between academic and collaborative components of human capital at the Adriatic maritime universities. The testing of the hypotheses proved the relevance of the key stance of the model - the higher academic (research) component of human capital for maritime research is, the higher is collaborative component (expertise and frequency of participation in maritime innovation projects), and vice versa.

In terms of practical contribution, the paper suggests the formation of collaborative platform that would match maritime universities and researchers with entrepreneurs, government, civil society, environmental and other organizations that are ready to innovate maritime industry through collaboration and thus contribute to the competitiveness and development of the Adriatic region. This idea could also extend to European stakeholders through numerous international maritime innovation projects.

The paper is rather exploratory and thus provides the basis for further empirical research. Further research should more precisely define human capital for maritime innovations, taking into account additional criteria such as: research knowledge, research competences, personality, working capacity, critical thinking, and other organizational and social characteristics of the teams for collaborative innovations. For the purposes of this study, the maritime researchers were asked to assess their own levels of expertise, and therefore, another survey in forthcoming years should check if the judgments of the maritime researchers have changed significantly since the first survey.

The examination of the individual aspects of academic human capital for fostering maritime innovations (researchers' human capital) represents a limitation of this research. In that sense, further research should investigate the collective capital of the scientific teams at the Adriatic maritime universities, which would have more complex, scientific and practical implications.

\section{REFERENCES / Literatura}

[1] Acciaro, M., Sys, C.: Innovation in the maritime sector: aligning strategy with outcomes, Maritime Policy \& Management, 2020, 47, pp. 1-19, https://doi.org $/ 10.1080 / 03088839.2020 .1737335$

[2] Blindenbach-Driessen, F., Van Dalen, J., Van Den Ende, J.: Subjective Performance assessment of innovation projects, Journal of Product Innovation Management, 2010, 27, pp. 572-592. Available online: https://doi. org/10.1111/j.1540-5885.2010.00736.x

[3] Chesbrough, H.W.: Open Innovation: The New Imperative for Creating and Profiting from Technology. Boston, USA, Harvard Business School Press, 2003. Available from: https://www.nmit.edu.my/wp-content/uploads/2017/10/ Open-Innovation-the-New-Imperative-for-Creating-and-Profiting-fromTechnology.pdf [Accessed 10th February 2021]. 
[4] Cimoli, M., Primi, A., Rovira, S.: National innovation surveys in Latin America: Empirical evidence and policy implications, Economic Commission for Latin America and the Caribbean (ECLAC), 2011, Available online: https://repositorio.cepal.org/bitstream/handle/11362/3903/S2011021. pdf? sequence $=1$ [Accessed: 1st May 2020].

[5] Coate, K., Barnett, R., Williams, G.: Relationships between Teaching and Research in Higher Education in England, Higher Education Quarterly, 2001 55(2), pp. 158-174, https://doi.org/10.1111/1468-2273.00180

[6] Da Silva Monteiro, J.P.V., Neto, P.A., Noronha, M.T.: Understanding the ways and the dynamics of collaborative innovation processes: the case of the maritime cluster of the Algarve region (Portugal), Urban, Planning and Transport Research, 2014, 2(1), pp. 247-264, https://doi.org/10.1080/216500 20.2014.909739

[7] De Frutos-Belizón, J., Martín-Alcázar, F., Sánchez-Gardey, G.: Conceptualizing academic intellectual capital: definition and proposal of a measurement scale. Journal of Intellectual Capital, 2019, 20(3), pp. 306-334, https://doi. org/10.1108/JIC-09-2018-0152

[8] De las Heras-Rosas, C., Herrera, J.: Research Trends in Open Innovation and the Role of the University, Journal of Open Innovation Technology Market and Complexity, 2021, 7(29), pp. 2-22, https://doi.org/10.3390/joitmc7010029

[9] Du, J., Leten, B., Vanhaverbeke, W.: Managing open innovation projects with science-based and market-based partners, Research Policy, 2014, 43(5), pp. 828-840, https://doi.org/10.1016/j.respol.2013.12.008

[10] European Commission. European Innovation Scoreboard 2020. Available online:https://ec.europa.eu/docsroom/documents/41941/attachments/1/ translations/en/renditions/native [Accessed: 23rd July 2020].

[11] Fruth, M., Teuteberg, F.: Digitization in maritime logistics-What is there and what is missing? Cogent Business \& Management, 2017, 4(1411066), pp. 1-40. https://doi.org/10.1080/23311975.2017.1411066

[12] Gallaud, D.: Collaborative Innovation and Open Innovation, In: Carayannis EG. (eds) Encyclopedia of Creativity, Invention, Innovation and Entrepreneurship New York, SAD, Springer, 2013, Available from: https://doi.org/10.1007/978-1 4614-3858-8 500 [Accessed 17th November 2020].

[13] García-Quevedo, J., Segarra-Blasco, A., Mercedes Teruel, M.: Financial constraints and the failure of innovation projects, document de trebal XREAP2016-02, 2016, Available online: http://www.urv.cat/media/ upload/arxius/catedra-innovacioempresarial/Recerca/J.Garcia\%20 Quevedo\%2C\%20A.Segarra\%2C\%20M.Teruel\%20Financial\%20constraints. pdf [Accessed: 1st May 2020].

[14] Granstrand, O., Holgersson, M.: Innovation ecosystems: A conceptual review and a new definition. Technovation, [In press: Online] 2020, Available from: https://doi.org/10.1016/j.technovation.2019.102098 [Accessed: 1st February 2021]https://doi.org/10.1016/j.technovation.2019.102098

[15] Gust-Bardon, I.N.: Regional Development in the Context of an Innovation Process, Working Papers Firms and Region, No.R5/2012, Available online: https://www.econstor.eu/obitstream/10419/60502/1/721228771.pdf [Accessed: 17th November 2020].

[16] Hoegl M, Gibbert M, Mazursky D. Financial constraints in innovation projects: When is less more? Research Policy. 2008; 37(8): 1382-1391. Available online: https://doi.org/10.1016/j.respol.2008.04.018

[17] Howell, D.C.: Chi-Square Test: Analysis of Contingency Tables, In: Lovric M. Eds. International Encyclopedia of Statistical Science, Berlin, Heidelberg, Springer, 2011, Available online: https://doi.org/10.1007/978-3-642-04898-2_174 [Accessed 1 December 2020].

[18] Ivošević, Š., Vidan. P.: Contents. Book of Proceedings 8th International Maritime Science Conference (IMSC), Budva, Montenegro, April 11th -12th, 2019, Faculty of Maritime Studies Kotor University of Montenegro, Faculty of Maritime Studies University of Split, Kotor, Montenegro, 2019, ISNN 18471498 , pp. I-VI.

[19] Koukaki, T., Tei, A.: Innovation and maritime transport: a systematic review, Case Studies on Transport Policy, 2020, 8(3), pp. 700-710, Available from: https://doi.org/10.1016/j.cstp.2020.07.009

[20] Mariz-Pérez, R.M., Teijeiro-Alvarez, M.M., García-Alvarez, M.T.: The relevance of human capital as a driver for innovation, Cuadernos de Economía - Spanish Journal of Economics and Finance Asociación Cuadernos de Economía, 2012, 35(98), pp. 68-76, Available online: https://www.elsevier.es/enrevista-cuadernos-economia-329-pdf-X0210026612551071., https://doi. org/10.1016/S0210-0266(12)70024-9

[21] Marzilli, C., Delello, J., Marmion, S., McWhorter, R., Roberts, P., Marzilli, T.S.: Faculty Attitudes towards Integrating Technology and Innovation, International Journal on Integrating Technology in Education (IJITE), 2014 3(1), pp. 1-20. Available online: https://doi.org/10.5121/ijite.2014.3101

[22] Monteiro, P., De Noronha, T., Paulo Neto, P.A.: Differentiation Framework for Maritime Clusters: Comparisons across Europe, Sustainability, 2013, 5(9), pp. 4076-4105, https://doi.org/10.3390/su5094076

[23] Pece, A.M., Simona, O.E.O., Salisteanu, F.: Innovation and Economic Growth: An Empirical Analysis for CEE Countries, Procedia Economics and Finance, 2015, 26, pp. 461-467, https://doi.org/10.1016/S2212-5671(15)00874-6

[24] Reichert, S. (European University Association): The Role of Universities in Regional Innovation Ecosystems, 2019, Available online: https://www.eua. eu/downloads/publications/eua\%20innovation\%20ecosystem\%20report_ final_digital.pdf [Accessed: 1st May 2020].

[25] Šekularac-Ivošević, S, Milošević, D. Innovation through collaboration: the application in maritime industry. 1st International Conference of Maritime Science \& Technology Naše More 2019, 17 - 18 October 2019, Croatia, Dubrovnik, ISBN 978-953-7153-52-6.

[26] Weiers, G.: Innovation through Cooperation: The Emergence of an Idea Economy, Springer, Cham, 2014, DOI: 10.1007/978-3-319-00095-4 [Accessed: 1st May 2020]. https://doi.org/10.1007/978-3-319-00095-4 